\title{
Investigation of the Effect of Combined Drying for Rainbow Trout Fillets and Comparison with Hot-air Drying
}

\author{
Osman İsmail ${ }^{1, *(1)}$, Özlem Gökçe Kocabay ${ }^{1,2}$
}

\footnotetext{
${ }^{1}$ Department of Chemical Engineering, Faculty of Chemical and Metallurgical Engineering, Yıldız Technical University, Davutpaşa Campus, 34210, Esenler, Istanbul, Turkey.

${ }^{2}$ T.R. Ministry of Culture and Tourism, Istanbul, Turkey.
}

\section{Article History}

Received Apr 11, 2019

Accepted Jun 27, 2020

First Online Jun 29, 2020

\section{Corresponding Author}

Tel.: +902123834774

E-mail: ismail@yildiz.edu.tr

\section{Keywords}

Fish

Moisture content

Modelling

Color

\begin{abstract}
In this study, drying kinetics, chemical composition and surface color for fillets samples, namely Rainbow trout (Oncorhynchus mykiss) subjected to combined drying (ultrasonic assisted vacuum drying) and hot-air drying were compared at full length between $50-70^{\circ} \mathrm{C}$. Drying process carried out entirely in the falling rate period. The results suggested that the moisture content was influenced by the combined drying method and the drying temperature. The shortest drying time was obtained using combined drying method at $70^{\circ} \mathrm{C}$. The combined drying method made shorter the drying process and enhanced the effective moisture diffusivity by comparison with hot-air drying method. The activation energies were observed using a modified Arrhenius type equation as of 2.392 and $4.83 \mathrm{~kW} \mathrm{~kg}^{-1}$ for combined and hot-air drying, respectively. Quality characteristics of fillets samples were specified as physical (moisture content, color values) and chemical (protein, fat and ash). Seven different drying models were considered for moisture ratios using nonlinear regression analysis. The consequences of regression analysis stated that the Midilli et al., model best fits data set. According to the results, the highest effective moisture diffusivity was determined in the fillets dried with the ultrasonic assisted vacuum drying method and they increased with increasing drying temperatures. Ultrasonic treatment accelerated the vacuum drying process for the fillets. Also, the ultrasonic assisted vacuum drying method is a better technology to preserve the original material and prevent thermal damage.
\end{abstract}

\section{Introduction}

Ever increasing world population and repeated starvation and lack of nutrition are top of the social and international issues. Fisheries sources are a significant resource of proteins, vitamins and micro-nutrients, most especially for a good deal of low-income populations in country side fields. Protein a significant nutriment that serves construct, keep up, and fix body tissue is commonly present in seafoods plus freshwater products (Beveridge et al., 2013).
Turkey has made significant improvements in fisheries production and consumption in recent years. Fisheries has an important position in closing the animal protein deficit of country population and reaching sufficient and balanced nutrition level. Substantial part of fishery products which are coached and preyed in Turkey are consumed as fresh. Another part is processed as animal feed in the fish meal and fat factories. This situation causes an important loss in national economy (Baygar et al., 2002). As well as fisheries it is a valuable foodstuff good in protein, because of having poor meat 
structure in respect of connective tissue it is a perishable foodstuff and in consequence of high $\mathrm{pH}$ and moisture content it deteriorates quicker according to other animal products.

Some conservation methods are used for rendering continuous consumption of fisheries by slowing down degradation process. One of the oldest known drying methods is open sun drying. Natural sundrying is carried out commonly in mostly tropic and subtropic countries and moreover in Turkey. Drying is an evaporation process of water had in the foodstuff under controlled conditions. The most important purpose of this process is increasing of working life of products which has short working life. In other words, it is the oldest fish hardling method which removes water amount of fish by drying and gets inappropriate level for reproduction and growing of bacteria. Recently microwave drying, ultrasonic vacuum drying, vacuum drying, high electric field drying and heat pump drying methods have been introduced to speed up the drying process considerably to give a product of acceptable quality and extended shelf life (Moses et al., 2014).

The ultrasonic vacuum drying technique, which is very rare in the literature, is a favourable method used to increase the dehydration rate without heating up of the foodstuffs under vacuum. Ultrasound is sound waves with frequencies superior than the top hearable limit of human hearing. In other words, ultrasound is a shape of mechanical energy led to by soundwaves with a frequency of farther than $20 \mathrm{kHz}$. Micro- distortion of porous solid materials, arising from ultrasonic waves, is probably liable for the formation of microscopic canals that promote diffusion and enhance convective mass transfer. Thus, ultrasound generates hollow, that is useful for the elimination of moisture which is robustly connected to the solid (Chemat et al., 2011).

Vacuum drying take place in the absence of oxygen and supplies efficient dehydration at moderate temperature, thus preserving majority of the food nutritious and sensorial properties (Reis, 2014). The ultrasonic vacuum drying method is an uncommon technic for food drying. The technic is based upon a combination of ultrasonic process and vacuum drying for reducing temperature and drying period. Also, with this technic, vacuum drying generates a peripheral pressure which is lesser than the atmospheric pressure and for this reason vaporizes water at low temperatures. The ultrasonic process, that is another major constituent of the technic, synchronically helps heat transfer and speeds up the water transportation from over the inner to the superficies of the material using mechanics waves (Başlar et al., 2015).

The purpose of this study is developing a favourable drying technic by connecting ultrasound and vacuum treatments and compare it with hot-air drying method. Rainbow trout fillets were dried between 50$70^{\circ} \mathrm{C}$ temperatures. Advantages of both drying methods (e.g., drying time and improving of dried food quality) were investigated. The experimental data is also fitted to seven thin-layer drying models, and effective moisture diffusivity and activation energy of fillets samples are computed.

\section{Materials and Methods}

\section{Materials}

Rainbow trout (Oncorhynchus mykiss) was acquired from Carrefour SA in Istanbul city of Turkey. The company (Carrefour SA) had purchased the fish from fish farms in the Bergama, Izmir. Weight and length range of the trout was $300-320 \mathrm{~g}$, and $25-35 \mathrm{~cm}$, respectively. The fillets were arranged with removal the head, tail plus bones from the fishes. Fillets were cut into pieces with an approximate lengthiness of $5 \pm 0.5 \mathrm{~cm}$, and thick of $1 \pm 0.2 \mathrm{~cm}$. Cut samples were brought to laboratory by placing into styrofoam with ice. To preserve their original quality, they were stored in a Arcelik 1050 model refrigerator for 30-60 minutes (Arcelik, Eskisehir, Turkey) at $4^{\circ} \mathrm{C}$ until drying experiments were done. Dry matter and moisture contents of the raw specimens were specified before drying treatment. To define the initial moisture content, four pieces 10 grams specimens were dried in a furnace (Memmert UM-400, Germany) at $105^{\circ} \mathrm{C}$ temperature for 24 hours (AOAC, 1990). Rainbow trout's average initial moisture content is calculated as $71.95 \%$ w.b.

\section{Chemical Analysis}

The crude protein of the trout fillet chemical composition was determined using a protein measuring instrument Leco FP-528 (Leco Corp., St. Joseph, MI, USA). Raw lipid (solvent extraction with petroleum ether B.P $40-60^{\circ} \mathrm{C}$ ) was determined with Soxhlet extraction method (FOSS Avanti automatic 2050, Sweden), and ash (furnace incineration at $525^{\circ} \mathrm{C}$ for $24 \mathrm{~h}$ ) was specified (AOAC, 2000).

\section{Drying Equipment and Drying Procedure}

\section{Hot-air Drying}

Drying tests were carried out in a cabin laboratory type dryer set up in the Chemical Engineering Department of Yildiz Technical University, Istanbul, Turkey. The cabin dryer was described previously by Doymaz (Doymaz, 2005).

Tests were carried out between $50-70^{\circ} \mathrm{C}$ temperatures. The fillets samples, $30 \mathrm{~g}$, was uniformly overspread in an quadrate basket in a mono sheet then by the desirable drying circumstances had stabilised. The weight loss of fillet samples was measured using a load cell (REVERE SHBXM CC) for 30 min intervals during drying. Drying process has been maintained until the final moisture content of the products reached to about $14 \%$ (w.b.). 


\section{Ultrasonic Assisted Vacuum Drying}

The fillets samples (about $30 \mathrm{~g}$ ) were dried using a combined drying system (ultrasound water bath and vacuum pump) at 50,60 and $70^{\circ} \mathrm{C}$ until the moisture content decreased to about $14 \%$ from an initial value of 71.95\%. An ultrasonic water bath (Alex, AXUY-08, Turkey) with a frequency of $40 \mathrm{kHz}$ combined using a vacuum pump (Rocker, 300 DC. Taiwan) with $650 \mathrm{mmHg}$ pressure and $25 \mathrm{~L} / \mathrm{min}$ pump speed was used for the ultrasonic assisted vacuum drying. In addition, the ultrasound water bath comprises a digital timer and a temperature controller. The tank capacitance of the laboratory bath was $8 \mathrm{~L}$ and it was loaded up approximate $6 \mathrm{~L}$ of distilled water. In this drying method, samples of fillets were put into a conical flask (the reactor was made as special design), which was associated with a vacuum pump. At that point, the flask containing of trout fillets was placed about $3 \mathrm{~cm}$ above the base of the ultrasonic water bath and connected to the vacuum pump. The temperature was measured using a thermometer and the water temperature in the bath was kept at $\pm 1^{\circ} \mathrm{C}$. The weight loss of fillets samples was determined every 30 minutes by measuring with an electronic balance (Mettler-Toledo AG, model BB3000, Grefensee, Switzerland).

\section{Mathematical Modelling of Drying Curves}

The moisture contents of fillets samples were transformed into dimensionless moisture ratio to do modeling studies easily. For designating effects of hotair and ultrasonic assisted vacuum drying on drying rate, the dried fillet samples have been weighed at regular intervals and the changes emerged at moisture rate during drying time have been calculated using the Equation of 1 (Darvishi et al., 2013):

$$
\mathrm{MR}=\frac{M \mathrm{t}-\mathrm{Me}}{M 0-\mathrm{Me}}
$$

where; $M_{t}$ is the mean fish samples moisture content at a specific time ( $g_{\text {water }} / g_{\text {dry matter }}$ ), $M_{o}$ and $M_{e}$ is the initial and equilibrium moisture content $\left(\mathrm{g}_{\text {water }} / \mathrm{g}_{\mathrm{dry}}\right.$ matter), respectively.

Moreover, effective diffusivity $\left(D_{\text {eff }}\right)$ values were calculated using the Equation of 2, (Ismail \& Kocabay, 2018) for fillets samples.

$$
M R=\frac{M_{t}}{M_{0}}=\frac{8}{\pi^{2}} \exp \left(-\frac{\pi^{2} \cdot D_{e f f}}{4 . L^{2}} t\right)
$$

In Equation 2, $D_{\text {eff }}$ is the effective diffusivity $\left(\mathrm{m}^{2} / \mathrm{s}\right)$; $t$ is the drying time (s) and $L$ is the half-thickness of the fillets samples $(\mathrm{cm})$. From Equation 2, a plot of In MR versus drying time should give a straight line with a slope

$$
\mathrm{K}=\frac{\pi^{2} \text { Deff }}{4 \mathrm{~L}^{2}}
$$

The dependence of the effective moisture diffusivity on temperature is described using the Arrhenius equation.

$$
D e f f=D 0 \exp \left(-\frac{E a}{R T}\right)
$$

In Equation 4, $D_{0}$ is the diffusivity for infinite temperature $\left(\mathrm{m}^{2} / \mathrm{s}\right), E_{a}$ is the activation energy $(\mathrm{W} / \mathrm{g}), R$ is the gas constant $(8.31451 \mathrm{~kJ} / \mathrm{mol} \mathrm{K})$ and $T$ is the drying temperature $(\mathrm{K})$.

In the present study, seven drying models that have been adapted to experimental results to examine drying kinetics are selected from the literature and given in Table 1. Statistica 6.0 program software (Statsoft Inc., Tulsa, OK) has been used in regretion analysis. The correlation coefficient $\left(R^{2}\right)$ has been taken as an important criterion to choose the best model to define the drying curves of the products. The root mean square error $(R M S E)$ and the reduced chi-square $\left(\chi^{2}\right)$ provide information about short-term performance and are used to determine the quality of suitability. The values of RMSE and $\chi^{2}$ are always positive but RMSE is represented as "zero" in the ideal case.

The root mean square error and the reduced chisquare could be computed from the using equations:

$$
\chi^{2}=\frac{\sum_{\mathrm{i}=1}^{\mathrm{N}}(\text { MRexp,i }- \text { MRpre, } \mathrm{i})^{2}}{\mathrm{~N}-\mathrm{z}}
$$

Table 1. Drying models selected to identify drying data of fillet samples

\begin{tabular}{lcc}
\hline Model name & Equation & References \\
\hline Lewis & $M R=\exp (-k . t)$ & (Başlar et al., 2014) \\
Henderson and Pabis & $M R=A_{o} \exp (-k . t)$ & (Henderson \& Pabis, 1961) \\
Page & $M R=\exp \left(-k \cdot t^{n}\right)$ & (Page, 1949) \\
Aghbashlo et al. & $M R=\exp \left(\left(-k_{1} . t\right) /\left(1+k_{2} . t\right)\right)$ & (Aghbashlo et al., 2009) \\
Alibas & $M R=a \exp \left(\left(-k \cdot t^{n}\right)+(b . t)\right)+g$ & (Alibas, 2012) \\
Logarithmic & $M R=a \exp (-k . t)+c$ & (Jain \& Pathare, 2007) \\
Midilli et al. & $M R=a \exp \left(\left(-k . t^{n}\right)+(b . t)\right)$ & (Midilli et al., 2002) \\
\hline
\end{tabular}




$$
R M S E=\left[\frac{1}{N} \sum_{i=1}^{N}(\text { MRpre }, i-M R \exp , i)^{2}\right]^{1 / 2}
$$

In equations, $N$ is the number of data values and $z$ is the number of constants. The lower the values of the RMSE and $\chi^{2}$, the better the goodness of fit. On the other hand, it is desirable that the $R^{2}$ value is close to " 1 ". Thus, the best model describing the drying properties of the samples is selected (Doymaz \& Altiner, 2012).

\section{Color Parameters}

The color of the fresh and dried fillets samples were determined using Minolta CR-200 Chroma Meter (Minolta Co., Osaka, Japan). Three random measurings for each selected sample were measured. The visual appearance of fresh and dried fillet samples was measured using a color-difference meter technique. A chromameter measures 3 parameters which are Hunter $L$, $a$, and $b$ values. ' $L$ ' value represents the brightness. ' $a$ ' value represents redness (+) or greenness (-). 'b' value represents yellowness $(+)$ or blueness (-) (Ismail \& Kocabay, 2018).

\section{Statistical Analysis}

One-way analysis of variance (ANOVA) was used to compare composition distinctnesses between fresh and dry trout fillets. The differences between the average values were compared using Tukey's multiple comparison test with a confidence range of $95 \%$ $(\mathrm{P}<0.05)$.

\section{Results and Discussion}

\section{Chemical Composition of Fillets Samples}

Trout fillets was measured before and after processing to determine the effect of processing on the chemical composition. The moisture content, protein, fat and ash percentage of raw and dried Rainbow trout fillets are shown in Table 2.

As seen Table 2, high moisture content, intermediate protein, low lipid and ash were observed in the raw samples. Moisture, protein, fat and ash values of fresh trout fillets were observed as about $72 \%, 21 \%$,
$3 \%$ and $1.6 \%$, respectively. Average percentage of moisture content, protein, fat and ash values calculated according to dry weight were observed as about $14 \%$, $70 \%, 9 \%$ and $5 \%$, respectively for ultrasonic assisted vacuum drying. In hot-air drying, these values were observed as about $14 \%, 72 \%, 8 \%$ and $5 \%$, respectively. The decrease in moisture content is the most significant change in dried trout fillets. Compared to fresh samples, protein, fat and ash contents increased significantly in dried samples $(P<0.05)$. The fat content of dried fillets is higher in ultrasonic assisted vacuum drying than hot-air drying. However, protein and fat contents of ultrasonically assisted vacuum and hot-air dried trout fillets were not statistically different $(P<0.05)$. The fat may spread with the moisture evaporation and prolonged heating process in the course of hot-air drying appears to promote this case. Başlar et al. (2015) observed the dry matter, protein, fat and ash content of the trout fillet close to our values. Similar results were obtained by Sajas and Gorbatow (1978) for meat.

\section{Drying Kinetics of Trout Fillets}

\section{Drying Curves}

The effect of three different temperatures and two different drying methods on the drying curves of fillets samples is shown in Figure 1.

As seen in Figure 1, ultrasonic assisted vacuum drying is a very important drying method that affects the drying time. Also, temperature is a very efficient factor for the fillets drying because it affects the drying time. As can be seen from the figures the drying time decreased with increasing drying temperature. Similar results have been reported by previous researchers for fish products (Darvishi et al., 2013; Ismail \& Kocabay, 2018).

Again, as shown in Figure 1, the drying time needed for drying of the fillet samples (water content: 14\%), with the ultrasonic assisted vacuum drying method at 50,60 and $70^{\circ} \mathrm{C}$ was observed as $7.0,5.5$ and $4 \mathrm{~h}$, respectively. Whereas, the drying time needed to reach final water content for hot-air drying method were 11.5, 7.5 and $5 \mathrm{~h}$, respectively. Decreasing the moisture content of aquatic products below $20 \%$ by weight prevents yeast, mold, enzyme and bacterial growth (Fellows, 2009; Kadam et al., 2015). The shortest drying time for trout fillet was obtained using ultrasonic assisted vacuum drying method at $70^{\circ} \mathrm{C}$ and it was observed to be about 1.25 times lower than the hot-air

Table 2. Chemical composition of trout fillets

\begin{tabular}{lccccc}
\hline Drying method & Product & Moisture content & Protein & Fat & Ash \\
\hline- & Fresh & $71.95 \pm 0.3$ & $20.74 \pm 0.2$ & $3.04 \pm 0.1$ & $1.64 \pm 0.1$ \\
UAVD & Dried & $14.00 \pm 0.5$ & $70.02 \pm 0.5$ & $8.78 \pm 0.5$ & $5.06 \pm 0.5$ \\
HAD & Dried & $14.00 \pm 0.6$ & $71.87 \pm 0.6$ & $8.21 \pm 0.6$ & $5.03 \pm 0.6$ \\
\hline
\end{tabular}

*Note. Means \pm SD are given in the Table; significantly $(\mathrm{P}<0.05)$ 

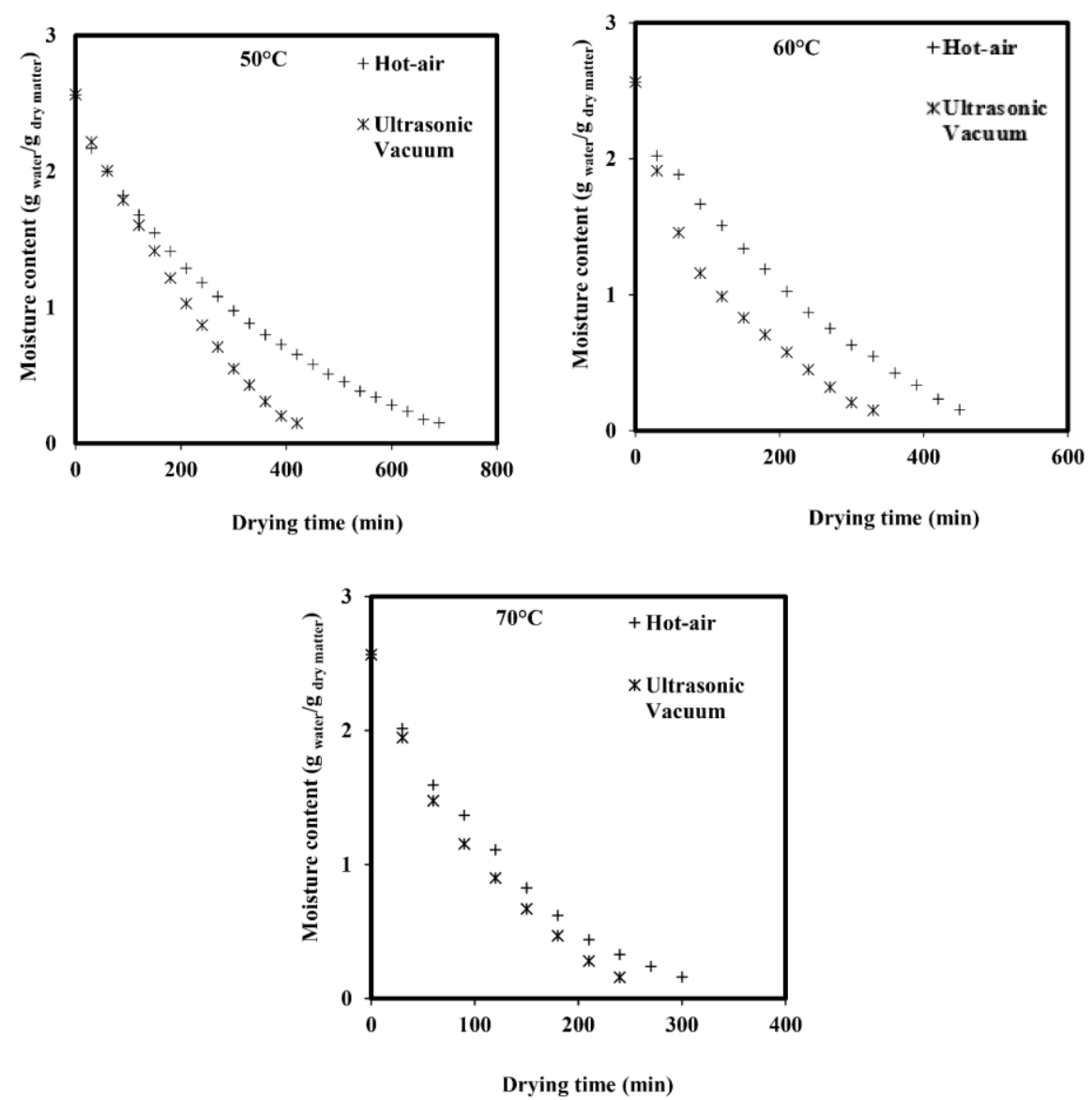

Figure 1. Drying curves of fillets dried with hot-air and ultrasonic assisted vacuum drying methods at different temperatures.

drying method. Whereas, this ratio was observed to be 1.64 and 1.36 at drying temperatures of 50 and $60^{\circ} \mathrm{C}$, respectively. Using of ultrasound leds to a series of effects on a medium that can influence mass transfer processes. This influence could be linked to effects on external or internal mass transfer resistance. Internal effect, mass transfer improvement is mainly could be linked to the changing pressure field within the product led to by ultrasounds. External mass transfer improvement is mainly due to the decrease in the boundary layer thickness (Sajas \& Gorbatow, 1978). As can be seen from the results, the ultrasonic assisted vacuum drying method accelerated the drying process of trout fillets at all three temperatures. This is due to the reduction of external resistance to mass transfer by deforming the cell membrane of the product using ultrasound (Rodríguez et al., 2014). As a result, ultrasound treatment increases the heat transfer coefficient which accelerates the removal of moisture from the sample (Kadam et al., 2015).

\section{Modeling of Drying Curves}

Drying kinetics and curve fitting procedures of the filletss samples were examined using the models of Lewis, Henderson \& Pabis, Page, Aghbashlo, Logaritmic, Alibaş and Midilli, equations.

To observe the accuracy of the models, coefficient of determination $\left(R^{2}\right)$, reduced chi-square $\left(\chi^{2}\right)$ and the root mean square error (RMSE) values are calculated and shown in Table 3. The acceptability of the model is based on $R^{2}, \chi^{2}$ and RMSE. The best model describing the thin-layer drying properties of fillets samples was selected with the highest $R^{2}$ values and the lowest $\chi^{2}$ and $R M S E$ values. The correlation coefficient $\left(R^{2}\right)$ varied between 0.9867 and 0.9999 for trout fillet samples. In other words, indicating a good fit since $R^{2}$ value close to unity implies that the predicted data were near the experimental drying data. This means that all established models successfully described the relation between time and MR. Other statistical parameters calculated to compare the accuracy of the model are $\chi 2$ and $R M S E$ values. The statistical parameters showed that the values of $\chi 2$ and $R M S E$ ranged from 0.000007 to 0.001051 and 0.002124 to 0.031035 , respectively as shown in Table 3. These two parameters are asked to be also close to zero. The relatively high values of correlation coefficients, low reduced chi-square, and low root mean square errors indicate a good predicting capacity for the drying conditions tested over the entire duration of the drying process. All the models showed good consistent with all the drying data of trout fillet samples. Thus, the empirical models chosen in this study suggested to be quite good to describe the drying behavior of trout fillet samples in the studied drying conditions. Based on the statistical test results $\left(R, \chi^{2}\right.$ and $R M S E$ ) Midilli et al. model gave better result compared to other models. Therefore, Midilli et al. model was 
Table 3. Estimated conformity parameter values of mathematical models for the drying kinetics of trout fillets at different temperatures and drying methods

\begin{tabular}{|c|c|c|c|c|c|c|c|}
\hline \multirow{2}{*}{ Models } & \multirow{2}{*}{ Parameters } & \multicolumn{3}{|c|}{ Ultrasonic assisted vacuum drying } & \multicolumn{3}{|c|}{ Hot-air drying } \\
\hline & & $50^{\circ} \mathrm{C}$ & $60^{\circ} \mathrm{C}$ & $70^{\circ} \mathrm{C}$ & $50^{\circ} \mathrm{C}$ & $60^{\circ} \mathrm{C}$ & $70^{\circ} \mathrm{C}$ \\
\hline \multirow{3}{*}{ Lewis } & $\mathrm{R}^{2}$ & 0.9942 & 0.9978 & 0.9949 & 0.9935 & 0.9972 & 0.9867 \\
\hline & $x^{2}$ & 0.00047 & 0.000200 & 0.000545 & 0.000516 & 0.001980 & 0.001051 \\
\hline & RMSE & 0.02085 & 0.013431 & 0.021842 & 0.02217 & 0.042962 & 0.031035 \\
\hline \multirow{3}{*}{$\begin{array}{l}\text { Henderson \& } \\
\text { Pabis }\end{array}$} & $\mathrm{R}^{2}$ & 0.9949 & 0.9982 & 0.9946 & 0.9947 & 0.9928 & 0.9900 \\
\hline & $x^{2}$ & 0.000449 & 0.000181 & 0.000634 & 0.000419 & 0.000649 & 0.000856 \\
\hline & RMSE & 0.019492 & 0.012039 & 0.021805 & 0.019547 & 0.023709 & 0.026703 \\
\hline \multirow{3}{*}{ Page } & $\mathrm{R}^{2}$ & 0.9987 & 0.9991 & 0.9962 & 0.9967 & 0.9988 & 0.9961 \\
\hline & $x^{2}$ & 0.00016 & 0.000092 & 0.000530 & 0.00030 & 0.000146 & 0.000422 \\
\hline & RMSE & 0.01080 & 0.008581 & 0.0203 & 0.01613 & 0.01066 & 0.018741 \\
\hline \multirow{3}{*}{ Aghbashlo et al. } & $\mathrm{R}^{2}$ & 0.9989 & 0.9995 & 0.9972 & 0.9961 & 0.9985 & 0.9946 \\
\hline & $x^{2}$ & 0.000093 & 0.00008 & 0.000293 & 0.000346 & 0.000162 & 0.000775 \\
\hline & RMSE & 0.009152 & 0.00727 & 0.015316 & 0.01723 & 0.01122 & 0.02269 \\
\hline \multirow{3}{*}{ Alibaş } & $\mathrm{R}^{2}$ & 0.9996 & 0.9999 & 0.9992 & 0.9985 & 0.9992 & 0.9995 \\
\hline & $x^{2}$ & 0.00296 & 0.000008 & 0.000175 & 0.00206 & 0.000099 & 0.00085 \\
\hline & RMSE & 0.03851 & 0.002207 & 0.010387 & 0.03836 & 0.008124 & 0.02263 \\
\hline \multirow{3}{*}{ Logarithmic } & $\mathrm{R}^{2}$ & 0.9990 & 0.9997 & 0.9980 & 0.9984 & 0.9990 & 0.9968 \\
\hline & $x^{2}$ & 0.000081 & 0.00008 & 0.000254 & 0.000189 & 0.000124 & 0.000611 \\
\hline & RMSE & 0.008385 & 0.00558 & 0.013001 & 0.011517 & 0.00909 & 0.01748 \\
\hline \multirow{3}{*}{ Midilli et al. } & $\mathrm{R}^{2}$ & 0.9997 & 0.9999 & 0.9997 & 0.9996 & 0.9998 & 0.9996 \\
\hline & $x^{2}$ & 0.000026 & 0.000007 & 0.000056 & 0.000044 & 0.000026 & 0.000045 \\
\hline & RMSE & 0.00455 & 0.002124 & 0.005553 & 0.005941 & 0.00376 & 0.005222 \\
\hline
\end{tabular}

accepted as the best model representing the ultrasonic assisted vacuum and hot-air drying behavior of trout fillet samples. The Midilli et al. model was also suggested by Darvishi et al. (2013) to describe drying of sardine fish.

\section{Effective Moisture Diffusivity and Activation Energy}

The moisture diffusivity of trout fillets samples was calculated using Equation 3. The effective moisture diffusivity values of trout fillets samples were shown in Table 4.

As seen from the table, the values of effective diffusivity for ultrasonic assisted vacuum drying and hotair drying were observed in the range of $2.57 \times 10^{-7}$ and $6.76 \times 10^{-7} \mathrm{~m}^{2} / \mathrm{s}$, respectively. The effective diffusivity increased with increasing drying temperature; it was also observed that the effective diffusivity values were higher for ultrasonic assisted vacuum drying method as compared to hot-air drying method.

Activation energy is defined as the minimum energy needed for the initiation and advancement of moisture transfer. The effect of the temperature on the moisture diffusion can be explained using Equation 4 and the activation energy was calculated by plotting $\ln \left(D_{\text {eff }}\right)$ versus the reciprocal of the drying temperature $(1 / T)$ as shown in Figure 2.

$D_{\circ}$ and Ea values are observed and calculated from the slope and intercept of the lines in the Figure 2. In other words, the slope of the line is $(-E a / R)$ and the intercept equals to $\ln \left(D_{0}\right)$. From the equations, the estimated values of Ea for fillets dried with ultrasonic assisted vacuum drying and hot-air drying were observed as 19.89 and $40.16 \mathrm{~W} / \mathrm{g}$, respectively. Ultrasonic assisted vacuum dried fillet samples showed lower activation energy than the hot-air dried fillet samples. One trend that should be noted is that the activation energy is inversely related to moisture content (Okos et al., 1992). This can be explained by the increase of the binding strength between the water and the fish samples at decreasing moisture content. The values of the activation energy lie from 12.7 to 110 $\mathrm{kJ} / \mathrm{mol}$ for most food materials (Zogzas et al., 1996).

\section{Color Analysis}

Changes in color characteristics of fresh and final dried fillets samples are shown in Table 5 showing that there were different results in terms of lightness, redness and yellowness among the drying methods.

Color is an important quality feature in the food industries and significantly influences the choice of consumer. The drying operation changes the surface characteristics of foods. This leads to reflectivity and color change (Fellows, 2009). As seen from the table, the drying temperature increase is the main factor affecting the color change of the dried sample.

As seen in Table 5, the color values of fillet samples before processing are: $L=48.3 \pm 0.1 ; a=19.0 \pm 0.2 ; b=$ $14.5 \pm 0.3$. A significant increase and decrease in $L$ and $b$ values were observed when compared to fresh trout fillets. In the case of the $L$ (lightness), the highest value was obtained in ultrasonic assisted vacuum drying at 60 and $70^{\circ} \mathrm{C}$, while there was no significant difference between the fresh and dried products at $50^{\circ} \mathrm{C}(P<0.05)$. On the other hand, a significant decrease is observed in 
Table 4. Values of effective moisture diffusivity obtained from fillets dried at different temperatures

\begin{tabular}{|c|c|c|}
\hline Temperature $\left({ }^{\circ} \mathrm{C}\right)$ & Drying method & $D_{\text {eff }}\left(m^{2} / s\right)$ \\
\hline & Ultrasonic assisted vacuum drying method & $4.39 \times 10^{-7}$ \\
\hline \multirow[t]{2}{*}{50} & Hot-air drying method & $2.57 \times 10^{-7}$ \\
\hline & Ultrasonic assisted vacuum drying method & $5.41 \times 10^{-7}$ \\
\hline \multirow[t]{2}{*}{60} & Hot-air drying method & $3.78 \times 10^{-7}$ \\
\hline & Ultrasonic assisted vacuum drying method & $6.76 \times 10^{-7}$ \\
\hline 70 & Hot-air drying method & $6.15 \times 10^{-7}$ \\
\hline
\end{tabular}

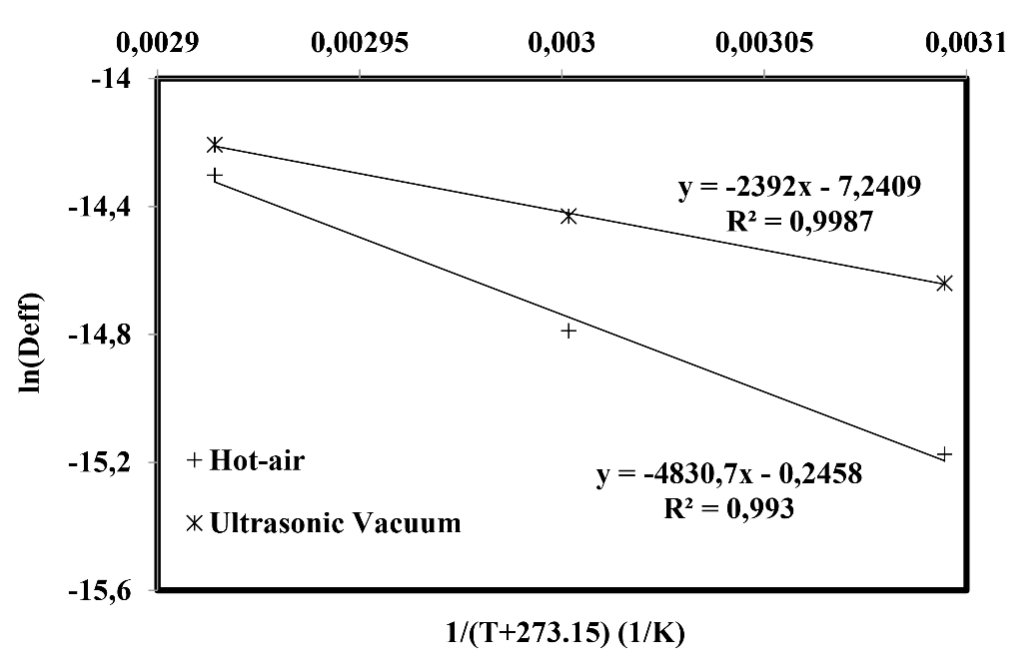

Figure 2. Variation of $\ln \left(D_{\text {eff }}\right)$ with $1 / T$.

Table 5. Color values of fresh and dried fillets samples

\begin{tabular}{|c|c|c|c|c|c|}
\hline Method & Temperature $\left({ }^{\circ} \mathrm{C}\right)$ & $L$ & $a$ & $b$ & $a / b$ \\
\hline \multirow[t]{2}{*}{ Fresh } & - & $48.3 \pm 0.1$ & $19.0 \pm 0.2$ & $14.5 \pm 0.3$ & 1.30 \\
\hline & 50 & $45.5 \pm 0.5$ & $13.4 \pm 0.2$ & $11.6 \pm 0.2$ & 1.15 \\
\hline \multirow{3}{*}{ Ultrasonic assisted vacuum drying } & 60 & $57.3 \pm 0.3$ & $13.5 \pm 0.2$ & $20.3 \pm 0.5$ & 0.67 \\
\hline & 70 & $60.6 \pm 0.3$ & $12.8 \pm 0.2$ & $20.4 \pm 0.2$ & 0.63 \\
\hline & 50 & $37.3 \pm 0.6$ & $12.1 \pm 0.7$ & $9.27 \pm 0.5$ & 1.30 \\
\hline \multirow{2}{*}{ Hot-air drying } & 60 & $43.7 \pm 0.4$ & $12.4 \pm 0.4$ & $11.1 \pm 0.2$ & 1.12 \\
\hline & 70 & $48.6 \pm 0.4$ & $13.4 \pm 0.2$ & $12.4 \pm 0.1$ & 1.08 \\
\hline
\end{tabular}

"a" values $(P<0.05)$. High " $L$ " and low "a/b" values are the desired properties in dried products. When ultrasonic assisted vacuum drying and hot-air drying are compared, trout fillets dried with ultrasonic assisted vacuum drying had the lower color change $(a / b)$ than hot-air drying at all temperatures. The larger $(a / b)$ values mean that larger total color change. According to Arslan et al. (2010) higher $L$ and lower $a / b$ are needed in dried foodstuff. The lowest color change was observed in ultrasonic assisted vacuum drying at $70^{\circ} \mathrm{C}$. As the drying temperature increases, the drying time decreases. In ultra high-temperature processing, the meat pigments change color, but there is very little caramelization or Maillard browning. For this reason, the operating temperatures should be kept low or some changes should be made to the drying method. Therefore, the ultrasonic assisted vacuum drying supplied shorter drying times than vacuum drying, resulting in lower total color change values. Descending drying time is very important for the food industry because the sea food contains oil that is reduced to peroxides when heat treatment is used (Contini et al., 2014). Lipid oxidation causes significant changes in color. As a result, fats may be less damaged when the trout fillets samples are dried using ultrasonic assisted vacuum drying.

\section{Conclusion}

In this study, the effects of different drying temperatures and drying methods on the drying characteristics and quality parameters of trout fillet samples were investigated and compared. Drying processes had no adverse effect on the protein and fat 
content. In both drying methods, the drying time significantly decreased with increased drying temperature. The effective moisture diffusivity varied between $2.57 \times 10^{-7}$ and $6.76 \times 10^{-7} \mathrm{~m}^{2} / \mathrm{s}$ and increased as temperature increased. The conclusion here is that the ultrasonic assisted vacuum drying method provides a shorter drying time and increased moisture diffusion. According to kinetic studies, the combination of ultrasound and vacuum reduced the activation energy (Ea) according to hot-air drying; on the other hand, increased the effective diffusivity ( $D_{\text {eff }}$ ). Estimated values of Ea for fillets dried with ultrasonic assisted vacuum drying and hot-air drying were observed as 19.89 and $40.16 \mathrm{~W} / \mathrm{g}$, respectively. Drying data of both drying methods were used to seven different drying models and it was seen that the Midilli et al., model was the best model. As the drying temperature increased, the brightness $(\mathrm{L})$ values increased and the color change $(a / b)$ values decreased of the products. The ultrasonic assisted vacuum drying method resulted in lower drying times and less color change as compared with conventional hot-air drying method. This study suggests that the ultrasonic assisted vacuum drying technique is a useful method for reducing the drying time and increasing the quality parameters of trout fillet samples.

\section{Conflict of Interest}

Authors do not have any conflict of interests to disclose nor do they endorse the use of any product/technology/service over the other.

\section{References}

Aghbashlo, M., Kianmehr, M. H., Khani, S., \& Ghasemi, M. (2009). Mathematical modelling of thin-layer drying of carrot. International Agrophysics, 23(4), 313-317. http://www.international-

agrophysics.org/Mathematical-modelling-of-thin-layerdrying-of-carrot,106450,0,2.html

Alibas, I. (2012). Microwave drying of grapevine (Vitis vinifera L.) leaves and determination of some quality parameters. Tarim Bilimleri Dergisi, 18, 43-53.

AOAC. (1990). Official methods of analysis (15th ed.). Association of Official Analytical Chemists.

AOAC. (2000). Meat and meat products. In: Official methods of analysis (17th ed.). Association of Official Analytical Chemists.

Arslan, D., Özcan, M. M., \& Mengeş, H. O. (2010). Evaluation of drying methods with respect to drying parameters, some nutritional and colour characteristics of peppermint (Mentha $\mathrm{x}$ piperita L.). Energy Conversion and Management, 51(12), 2769-2775. https://doi.org/https://doi.org/10.1016/j.enconman.20 10.06.013

Başlar, M., Kılıçlı, M., Toker, O. S., Sağdıç, O., \& Arici, M. (2014). Ultrasonic vacuum drying technique as a novel process for shortening the drying period for beef and chicken meats. Innovative Food Science \& Emerging Technologies, 26, 182-190. https://doi.org/https://doi.org/10.1016/j.ifset.2014.06. 008

Başlar, M., Kılıçlı, M., \& Yalınkılıç, B. (2015). Dehydration kinetics of salmon and trout fillets using ultrasonic vacuum drying as a novel technique. Ultrasonics Sonochemistry, 27, 495-502. https://doi.org/https://doi.org/10.1016/j.ultsonch.2015 .06 .018

Baygar, T., Erkan, N., Mol, S., Özden, Ö., \& Varlik, C. (2002). Determination of the shelf-life of stuffed Rainbow trout during cold storage. Turkish Journal of Veterinary and Animal Sciences, 26, 577-580.

Beveridge, M. C. M., Thilsted, S. H., Phillips, M. J., Metian, M., Troell, M., \& Hall, S. J. (2013). Meeting the food and nutrition needs of the poor: the role of fish and the opportunities and challenges emerging from the rise of aquaculturea. Journal of Fish Biology, 83(4), 1067-1084. https://doi.org/10.1111/jfb.12187

Chemat, F., Zill-e-Huma, \& Khan, M. K. (2011). Applications of ultrasound in food technology: Processing, preservation and extraction. Ultrasonics Sonochemistry, 18(4), 813835.

https://doi.org/https://doi.org/10.1016/j.ultsonch.2010 .11 .023

Contini, C., Álvarez, R., O’Sullivan, M., Dowling, D. P., Gargan, S. Ó., \& Monahan, F. J. (2014). Effect of an active packaging with citrus extract on lipid oxidation and sensory quality of cooked turkey meat. Meat Science, 96(3),

1171-1176. https://doi.org/10.1016/j.meatsci.2013.11.007

Darvishi, H., Azadbakht, M., Rezaeiasl, A., \& Farhang, A. (2013). Drying characteristics of sardine fish dried with microwave heating. Journal of the Saudi Society of Agricultural Sciences, 12, 121-127. https://doi.org/10.1016/j.jssas.2012.09.002

Doymaz, I. (2005). Drying characteristics and kinetics of okra. Journal of Food Engineering, 69(3), 275-279. https://doi.org/https://doi.org/10.1016/j.jfoodeng.200 4.08.019

Doymaz, I., \& Altiner, P. (2012). Effect of pretreatment solution on drying and color characteristics of seedless grapes. Food Science and Biotechnology, 21(1), 43-49. https://doi.org/10.1007/s10068-012-0006-4

Fellows, P. (2009). Food processing technology (2nd ed., pp. 273-337). Woodhead Publishing Limited.

Henderson, S. M., \& Pabis, S. (1961). Grain drying theory I. Temperature effect on drying coefficient. Journal of Agricultural Engineering Research, 6, 169-174.

Ismail, O., \& Kocabay, O. G. (2018). Infrared and microwave drying of Rainbow trout: Drying kinetics and modelling. Turkish Journal of Fisheries and Aquatic Sciences, 18, 259-266. https://doi.org/10.4194/1303-2712-v18

Jain, D., \& Pathare, P. B. (2007). Study the drying kinetics of open sun drying of fish. Journal of Food Engineering, 78(4), 1315-1319. https://doi.org/https://doi.org/10.1016/j.jfoodeng.200 5.12 .044

Kadam, S. U., Tiwari, B. K., \& O’Donnell, C. P. (2015). Effect of ultrasound pre-treatment on the drying kinetics of brown seaweed Ascophyllum nodosum. Ultrasonics Sonochemistry, 23, 302-307. https://doi.org/https://doi.org/10.1016/j.ultsonch.2014 .10 .001 
Midilli, A., Kucuk, H., \& Yapar, Z. (2002). A new model for single-layer drying. Drying Technology, 20(7), 15031513. https://doi.org/10.1081/DRT-120005864

Moses, J. A., Norton, T., Alagusundaram, K., \& Tiwari, B. K. (2014). Novel drying techniques for the food industry. Food Engineering Reviews, 6, 43-55. https://doi.org/10.1007/s12393-014-9078-7

Okos, M. R., Narsimhan, G., Singh, R. K., \& Witnauer, A. C. (1992). Food dehydration (D. R. Heldman \& D. B. Lund (eds.)). Marcel Dekker.

Page, G. E. (1949). Factors influencing the maximum rates of air-drying shelled corn in thin layers. Purdue University.
Reis, R. (2014). Vacuum drying for extending food shelf-life. Springer.

Rodríguez, J., Mulet, A., \& Bon, J. (2014). Influence of highintensity ultrasound on drying kinetics in fixed beds of high porosity. Journal of Food Engineering, 127, 93-102. https://doi.org/https://doi.org/10.1016/j.jfoodeng.201 3.12.002

Sajas, J. F., \& Gorbatow, W. M. (1978). Use of ultrasound in meat technology. Fleischwirtschaft, 58(6), 1009-1021.

Zogzas, N. P., Maroulis, Z. B., \& Marinos-Kouris, D. (1996). Moisture diffusivity data compilation in foodstuffs. Drying Technology, 14(10), 2225-2253. https://doi.org/10.1080/07373939608917205 